\title{
BIG BLUE BUTTON FOR E-LEARNING: THE EFFECT OF PRIVACY AND SUPPORT QUALITY
}

\author{
Zahra Ibrahim Al hashimi \\ College of Commerce and Business Adminstration, \\ Dhofar University
}

\begin{abstract}
The aim of this study is to determine most important characteristics of e-learning for the teacher and students and the challenges they face. More specifically the effect of Privacy and Support Quality on Intention to use Big Blue Button for e-learning.

Primary data was collected using online questionnaire, only 133 responses were valid for analysis. The measurement items for the variables were adopted from validated instruments and published articles and books used as a secondary source for getting data for this study. An appropriate statistical analysis tests were used to check the instrument reliability (Cronbach's alpha) and testing research hypotheses (multiple linear regression test). To get this statistical test done the SPSS software was used. The findings show that privacy does not affect the intention to use the big blue button for e-learning, as well as the lack of quality support affects the intention to use the big blue button. Where both variables are most prominent in the use of the big button for e-learning. It is necessary to provide development experts with the necessary support to develop educational platforms to make them more reliable and more effective.
\end{abstract}

Keywords - Privacy, Support Quality, Big Blue Button for e-learning and e-learning.

\section{INTRODUCTION}

The development and invention of the Internet led to the development of educational processes using some modern methods of learning. Computers, networks, programs and modern educational platforms, which led to the development and ease of electronic education[1]. E-learning also removed many educational problems and facilitated the learning process, such as the Corona pandemic today, and facilitated platforms Modern education and learning have helped reduce the spread of the virus among students [2]. Distance learning also encouraged students to face challenges and difficulties and develop their skills and ability to learn. The educational processes also helped to create, interact and develop skills through the latest methods in the fields of education such as MODEL and Blue Button programs and educational platforms for each educational institution, computers, storage media and networks where it strengthened and facilitated the process of self-education and the transfer of knowledge and skills from the teacher to the student. One of the most used educational platform today is the Big blue button is basically a web conferencing system which is designed for various online classes or learning. The use of advanced technology and elearning is becoming more common nowadays in educational institutes for learning purposes. This way of learning has been increased nowadays. Big Blue Button is the best solution for e-learning and provides the accurate and authentic sharing of audio, screen, video, chat as well as whiteboard for the class. This also provides the facility for the participants to join the conferences by their webcams. By these method guest speakers are also invited to the conference. This Moodle is a global platform that authorized the instructors to create a private online space by which instructors build and develop the courses as well as activities [3]. These activities build with the help of different and flexible tools provided by that software for the efficient online or e-learning. The main aim of that module is to empower the instructors and educational system to improve and conquer the world. Education is the key factor by which we improve and conquer the world. By getting knowledge we make the world a better place for living. Learning is a process that is going and continuous for all over the time. In this way we also help others in learning and also teach them in a better way.

This Moodle cloud of learning was officially released almost fourteen years ago. There are thousands of education sites that are hosted by this Moodle cloud. By this mood there is an option for the Big Blue Button to purchase and has accessibility for online learning. This is an efficient and attractive way of learning. The CEO of this Moodle explains that these added features helped and allowed a lot of instructors as well as students to cooperate, participate and captivate in the online learning. In this way the education system becomes more attractive and interrelated [3]. The main aim and mission of this Moodle is to help the people to improve the educational system. The learning is improved by use of this technology. This is the best way and is highly appreciated by instructors. The users of this software plays an important role in solving the technical problems and thus support this software.

This Moodle cloud have a high access towards the web of having high quality. This software helps a lot in building and showing the video of high quality. This Moodle or Big Blue Button provides this service for all the school sites that are present at Moodle. This also introduce a new feature of portal [4]. In this log in to the portal and upgrade the plan 
that you have and then purchase the add-ons. This option is only available for different school sites and there are almost 30 users of Big Blue Button apply for each site.

Higher education institutes are attracting their students by introducing programs of e-learning. The competition between the institutes increased. In this way the institutes invest a lot of money for the courses of e-learning and the learning management system. This investment provides an e-learning platform to the students. e-learning changed the educational system at a great extent and thus in this way students connect with higher authorities. E-learning and learning management systems are basic tools in helping the students to build their knowledge, enhance their communication skills and also develop their social networking by which their interaction with other people has been increased. The collaboration of students enhances their various skills such as improving their power of thinking, level of understanding and thus after that the task is done by students with high efficacy and accuracy.

The use of e-learning enhances the self confidence in students and also provides the opportunity to students to give justification of their ideas. This provides such an environment to the students that students can interact with other students and provide an opportunity for more discussion. The level of learning in students is enhanced by this way of learning. Learning management system facilitates the e-learning in students and instructors.

According to HABIB (2020) and others, it is not possible to achieve e-learning without modern technology and the Internet [5]. As TOSHIYA (2020) and others indicated that using computers as an alternative to client server models reduces costs and storage problems [6]. According to Natalia's study (2020) to facilitate the use of educational platforms We must create training courses in English [7]. According to ELTAYEB and ELDIN (2020) we have a positive attitude towards the use of educational platforms and the willingness of faculty to implement it[8]. According to DIANE and DESIREE (2015), the foundations of education are a basic base of knowledge leading to implementation [9]. As all studies are Affect e-learning. E-learning is the use of ICT in offering learner's information and knowledge services by giving away time and geography. The use of electronic tools is combined with digital education, where information, communication, instruction, and training are given online, structuring e-learning [10].The effectiveness of e-learning programs can be measured by the intention to use e-learning, also known as the intention to use it. Companies who wish to prevent the lack of use of technology will concentrate on the introduction of appropriate approaches to enable consumers to continue to utilize their tools and interests. Study with the aim to use highlights the study of the history to the potential expanded expected use of technology. The theory of rational movement (TRA) is one of the theoretical models built for the study of the user 's behavior, and according to TRA, the user aims to perform a certain action or not at all. The user 's perspective and subjective values will affect the intention to use technology. But when a certain action is performed, the lack of incentives, expertise, and resources can very well hinder it. Therefore, the TRA was expanded to include an additional progression component, namely perceived behavioral regulation, using the theory of expected actions (TPB). Perceived regulation of actions explains the understanding of a person's ability to execute a certain order, and its self-efficacy is part of it. The TPB model elements, namely behaviors, moral beliefs, and perceived behavioral regulation, collectively clarify conduct intentions and are commonly used to study the actions of the individual in conjunction with e-learning implementation [11]. Jacsó, (2007) proposed that the production and implementation of these programs should be changed to ensure that these metrics are taken into consideration in strategic arrangement through the determination of the metrics that affect the use of elearning, educational managers and designers and facilitators [12]. Help for management is the perceived level of general assistance to web-based management plans, including help for services and encouragement. The degree to which an individual assumes that using a machine enhances job efficiency and the function is referred to as a perceived utility

According to Simonson, (2015), stated that the intention of e learning may vary person to person. Selfeffectiveness refers to the assumption that needs have the potential to inspire, cognitive resources, and movement courses required to fulfill the demands of a particular situation[11].

Whatever, electronic learning (e-learning), like other e-commerce application, still not investigated sufficiently. In the context of the study the adoption of technology has been investigated by few research, work process digitalization[13], providing e-government services from citizens as well as employees perspectives [14]-[16], accepting E-Mail System University Students[17], Clients acceptance of Internet Banking[18], adopting ICT by SMEs employees [19], and customers attitudes to adopt e-shopping [20]. Moreover, from the teaching assessment perspective also few studies has been done in the context of the study[21]. Therefore, This research examines the influence of e-learning in the educational sector. The study is conducted to check whether the use of e-learning in the educational sector improves the level of learning and understanding in students or not. It was also done how the use of e-learning is enhanced by instructors and also the use of Big Blue Button for the success of the educational sector.

\section{LITERATURE REVIEW}

E-learning depends on a number of factors that contribute to achieving the efficiency of e-learning, such as the services provided by educational platforms, the quality of performance, privacy, communication networks and modern technologies. KAURAV (2019) and others have demonstrated the impact of technological progress on education and its response to learners' needs [22]. According to HALIL and 
SINAN (2020), the development of technology and the Internet has an impact on the progress of education [23]. Young (2011), stated that the Privacy and Support Quality are the most important aspects in the e-learning leads increased ability, expertise, and awareness of employees are one of the key advantages of e-learning at the authoritative level. Human resources for investing in human assets are said to be placing partnerships in a better position that is exposed to long-term advantages. Humans require expertise, abilities, partnerships, competences, and innovation present in employees. Through offering and facilitating training for employees in the business world, businesses are able to gain advantages such as an increase in employee earnings, were mistakes that could have money-based and republic solutions are successfully and efficiently accomplished. Another advantage of e-learning has improved the quality of items and services provided, as research and development, sales, marketing, and operational teams are increasingly competent, skills and knowledge, and have an ability to ensure that their performance continuously improves. The last advantage stated by Young (2011), the financial support of employee competence programs, is that strategic approaches, innovative products, and services are planned and developed as a result of the enhanced degree of expertise and cooperation within the alliance.

The study will focus on the effects of privacy and quality support on e-learning. E-learning is a means that supports educational processes through modern technologies such as computers and networks, etc.; it aims to interact and develop skills and transfer of knowledge between participants in educational platforms. This study will determine privacy and support quality first, then it will continue to prove the hypothesis positively by focusing on the following variables.

Privacy: It is the right of the individual and the preservation of his personal information and data while entering or browsing the internet sites and not showing it to others to avoid the theft of confidential or personal information and using it for unlawful purposes and exposing the individual to extortion and others by hackers. Different people define privacy as protecting personal information or data. At the beginning of the year (2011) Anwar and Greer identified privacy as protecting personal information through (IM) and that it is a trusting relationship in the e-learning environment between learners. In (2007) E, Aïmeur, E, Hage and F, Onana defined privacy as keeping people private parts of their personal files and not showing them to others[24]. According to c, kiennert and others (2017) privacy refers to the protection of the individual in relation to the protection of his information and personal data and the freedom of movement of his data in strict confidentiality and accuracy and storage and others [25].D, xiaozhao (2009) studies this, according to what he says is protecting the privacy of personal data such as hiding their identity and not leaking it to protect individuals from threats and extortion.D, xiaozhao and ( $R$, Jianhai (2009) study this, and according to him, it protects the privacy of users' data, hides it as an identity, and does not leak it to protect individuals from threats and extortion [26].According to J, Yong (2007) that privacy is the protection of personal data, we can generally understand what privacy is the ability of an individual to maintain his or her confidential or personal information and not to show it to others[27].

Support Quality: The concept of quality in e-learning is interesting and also modern today because of the conditions we are experiencing from the Corona pandemic and the total dependence on e-learning. Despite the existence of challenges and problems in e-learning or educational platforms, only humanity is trying and doing their best in developing elearning And educational platforms and the elimination of problems to become of high quality and completely reliable in the coming days. According to the JAN and PETER (2019) study, using conceptual modeling in e-learning and measuring its impact on the quality of e-learning [28]. According to ANTONIA (2020) study, through digital devices we can access information and create high-quality education opportunities [29]. We can also improve Quality in physics learning planning materials using PJBL in WANYU and IRFAN (2020) educational activities[30]. According to the Krissia and Ivan (2018) study, the impact of stakeholders and quality on users during the development of educational platforms [31]. For the success of e-learning services, improvement of educational services must be demonstrated through development and increased reliability Al Taie and Fathi (2020). According to (Roberts, 2004), The benefits of elearning can be associated with cost savings, changes in the learning process, learning benefits, educational benefits, and authoritative benefits [32]. Cost savings assets can be realized by e-learning due to the utilization of transportation, services, and materials. An increase in the quality of learning is accomplished with the help of e-learning apps that can also help to attract students into a deeper learning experience. Learners may benefit from having access to learning tools from each region and pursuing a speed that is conducive to their individual styles of learning. Two benefits for teachers are that they can make learning from any area easy by reducing travel and secondly by providing diverse material for learning. Based on above reviewed literature the following hypotheses are suggested which are represented in figure 1 the suggested research model:

H1: Privacy does not affect the intention to use the blue button for e-learning in educational institutions.

$\mathrm{H} 2$ : Quality support does not affect the intention of maintaining the big blue e-learning button in educational institutions. 


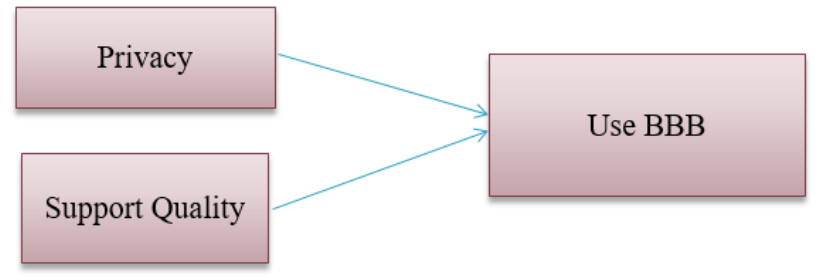

Figure 1: Study Model

\section{RESEARCH METHODS}

This study will be done in the academic frame. The study is aimed to determine the effect of Privacy and Support Quality on Intention to use Big Blue Button for e-learning.

Primary data was collected using online questionnaire, only 133 responses were valid for analysis. The measurement items for the variables were adopted from validated instruments[33], [34] and published articles and books used as a secondary source for getting data for this study.

An appropriate statistical analysis tests were used to check the instrument reliability (Cronbach's alpha )[35]-[37] and testing research hypotheses (multiple linear regression test)[38], [39]. To get this statistical test done the SPSS software was used.

IV. ANALYSIS

Table 1 reliability test

\begin{tabular}{lc}
\hline Variable & Cronbach's Alpha \\
\hline Privacy & 0.655 \\
Support Quality & 0.851 \\
Use BBB & 0.871 \\
\hline
\end{tabular}

Multiple regression analysis used for hypotheses testing. Its results presented in the following tables $(2,3,4)$

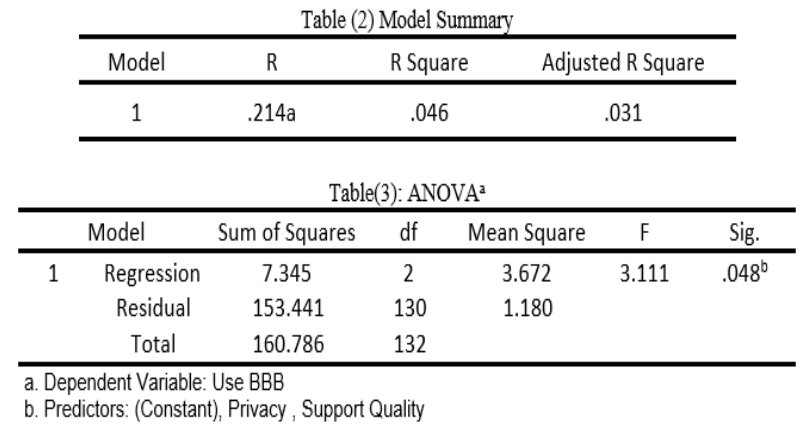

\begin{tabular}{|c|c|c|c|c|c|c|}
\hline \multicolumn{7}{|c|}{ Table(4): Coefficients ${ }^{\mathrm{a}}$} \\
\hline & \multirow[t]{2}{*}{ Model } & \multicolumn{2}{|c|}{$\begin{array}{c}\text { Unstandardized } \\
\text { Coefficients }\end{array}$} & \multirow{2}{*}{$\begin{array}{c}\text { Standardized } \\
\text { Coefficients }\end{array}$} & \multirow[t]{2}{*}{$\mathrm{T}$} & \multirow[t]{2}{*}{ Sig. } \\
\hline & & B & Std. Error & & & \\
\hline \multirow{3}{*}{1} & (Constant) & 2.273 & .596 & & 3.811 & .000 \\
\hline & $\begin{array}{l}\text { Support } \\
\text { Quality }\end{array}$ & -.027 & .111 & .021 & .245 & .807 \\
\hline & Privacy & .290 & .116 & .215 & 2.494 & .014 \\
\hline
\end{tabular}

In this study the effect of two independent variables (Privacy , Support Quality) have been tested Both of them as displaied in table (2) $(\mathrm{R} 2=0.046)$ have explained $(4.6 \%)$ of the variance in Intention to use Big Blue Button for e-learning. Table (3) shows $\mathrm{F}$ test $(\mathrm{F}=3.11)$ is significant at $(\mathrm{P}<$ $0.05)$. The results of regression analysis shows that Privacy, has a significant positive effect $(\beta=0.215$, sig. $=0.014)$ on Intention to use Big Blue Button for e-learning see table (4). While. Support Quality has no significant effect $(\beta=0.021$, sig. $=0.807)$ on Intention to use Big Blue Button for elearning.

\section{DISCUSSION}

The study found the privacy has very weak effect on the Use BBB this result is in disagree with results of [24] and others defined privacy as keeping people private parts of their personal files and not showing them to others. xiaozhao (2009) studies this, according to what he says is protecting the privacy of personal data such as hiding their identity and not leaking it to protect individuals from threats [26]. With Privacy affects the use of the button because privacy is very important for keeping confidential data for students.

The study found the support quality has no effect on the Use BBB. This result is in disagree with results JAN and PETER (2019) study, using conceptual modeling in e-learning and measuring its impact on the quality of e-learning [28]. According to ANTONIA (2020) study, through digital devices we can access information and create high-quality education opportunities [29]. with Quality has a major impact on elearning, the higher the quality of e-learning, the more it becomes more reliable and effective by educational institutions 
However, e-learning enhances education, especially in our current circumstances with the Covid-19. Studies have proven the effectiveness of e-learning in helping it to complete the study in the best way and achieve interaction and develop students 'skills. But there are some of the more common challenges facing e-learning such as privacy and quality, so Education systems must be developed and developed to make them more effective and quality. Also, provide educational platforms with more secure and private systems to protect student data.

To conclude, the study aimed to demonstrate the extent to which privacy affects the use of the big blue button for e-learning. The study also concluded that quality support has no impact on the intention to use the big blue button for elearning, so if quality and privacy are combined at the same time, e-learning becomes more effective and Efficiency and meets the needs of learners. It is very important to develop educational platforms and eliminate problems or factors that negatively affect e-learning, such as quality of performance, ease of use, security, and others, so it is adviseable that educational bodies to continue studying using these modern techniques and develop skills and interaction between learners.

\section{REFERENCE}

[1] M. Z. M. Nor and A. M. Mohamad, "Challenges in Accepting the E-Learning System: The Case of ELearners from Different Backgrounds of Study," in 3rd International Conference on E-Learning and Distance Learning, 2013, Accessed: 31-Jul-2020. [Online]. Available: https://www.researchgate.net/publication/260210545_ Challenges_in_Accepting_the_E-

Learning_System_The_Case_of_E-

Learners_from_Different_Backgrounds_of_Study.

[2] N. Croft, A. Dalton, and M. Grant, "Overcoming Isolation in Distance Learning: Building a Learning Community through Time and Space," J. Educ. Built Environ., vol. 5, no. 1, pp. 27-64, Jul. 2010, doi: 10.11120/jebe.2010.05010027.

[3] C. M. N. Faisal, D. Fernandez-Lanvin, J. De Andrés, and M. Gonzalez-Rodriguez, "Design quality in building behavioral intention through affective and cognitive involvement for e-learning on smartphones," Internet Res., vol. ahead-of-print, no. ahead-of-print, Jul. 2020, doi: 10.1108/INTR-05-2019-0217.

[4] C. S. Christou, D. Ktoridou, and K. Zafar, "A costeffective computer supported collaborative learning for online education," in IEEE Global Engineering Education Conference, EDUCON, 2016, vol. 10-13April-2016, pp. 1138-1144, doi: 10.1109/EDUCON.2016.7474698.

[5] H. Ibrahim, S. Karabatak, and A. A. Abdullahi, "A Study on Cybersecurity Challenges in E-learning and Database Management System," in 8th International
Symposium on Digital Forensics and Security, ISDFS 2020, 2020, doi: 10.1109/ISDFS49300.2020.9116415.

[6] T. Kawato, M. Higashino, K. Takahashi, and T. Kawamura, "Proposal of distributed e-learning system using idle resources," in 2020 5th International Conference on Computer and Communication Systems, ICCCS 2020, 2020, pp. 557-561, doi: 10.1109/ICCCS49078.2020.9118598.

[7] N. A. Kopylova, "The Use of Modern E-learning Technologies at English Lessons in a Technical University Pedagogical Process," in 2020 9th Mediterranean Conference on Embedded Computing, MECO 2020, 2020, doi: 10.1109/MECO49872.2020.9134257.

[8] G. eldin A. Eltayeb, "THE REALITY OF USING ELEARNING APPLICATIONS AND THE READINESS OF FACULTY MEMBERS: A CASE STUDY," Int. J. Adv. Res. Comput. Sci., vol. 11, no. 3, pp. 37-41, Jun. 2020, doi: 10.26483/ijarcs.v11i3.6621.

[9] D. Elkins and D. Pinder, E-Learning Fundamentals: A Practical Guide. American Society for Training and Development, 2015.

[10] A. Taha, "Knowledge maps for e-literacy in ICT-rich learning environments," J. Libr. Inf. Serv. Distance Learn., vol. 2, no. 4, pp. 67-78, Apr. 2007, doi: 10.1300/J192v02n04_06.

[11] M. Simonson, "Designing the 'Perfect' Online Course," Greenwich, vol. 12, no. 1, pp. 5-7, 2015.

[12] P. Jacsó, "Options for presenting search results: Part I - Common options," Online Inf. Rev., vol. 29, no. 3, pp. 311-319, 2005, doi: $10.1108 / 14684520510607614$.

[13] M. N. Alraja, M. A. Hussein, and H. M. S. Ahmed, "What affects digitalization process in developing economies? an evidence from SMEs sector in Oman," Bull. Electr. Eng. Informatics, vol. 10, no. 1, Feb. 2021, doi: 10.11591/EEI.V10I1.2033.

[14] M. N. Alraja, S. Hammami, and T. Alhousary, "Factors affecting e-government services adoption: Field study," J. Theor. Appl. Inf. Technol., vol. 78, no. $1,2015$.

[15] M. N. Alraja, S. Hammami, B. Chikhi, and S. Fekir, "The influence of effort and performance expectancy on employees to adopt E-government: Evidence from Oman," Int. Rev. Manag. Mark., vol. 6, no. 4, 2016.

[16] M. N. Alraja, "The effect of social influence and facilitating conditions on e-government acceptance from the individual employees' perspective | Efekt Wpływu Społecznego Oraz Warunków Ułatwiających Akceptację E-Administracji Z Punktu Widzenia Indywidualnych Pracowników," Polish J. Manag. Stud., vol. 14, no. 2, 2016, doi: 10.17512/pjms.2016.14.2.02.

[17] M. N. Alraja, "User Acceptance of Information Technology: A Field Study of an E-Mail System 


\section{International Journal of Engineering Applied Sciences and Technology, 2020 \\ Vol. 5, Issue 3, ISSN No. 2455-2143, Pages 59-65 \\ Published Online July 2020 in IJEAST (http://www.ijeast.com)}

Adoption from the Individual Students' Perspective," Mediterr. J. Soc. Sci., vol. 6, no. 6 s1, pp. 19-25, Nov. 2015, doi: 10.5901/mjss.2015.v6n6s1p19.

[18] M. N. Alraja, B. F. Salim, M. A. Uddin, and M. Yousoof, "The adoption of internet banking: Clients' perspective in Oman," Int. Rev. Manag. Mark., vol. 6, no. 4, 2016.

[19] M. A. Hussein, H. Ahmed, and M. N. Alraja, "The adoption of information and communication technology by small and medium enterprises in Oman: Case of Dhofar region," J. Bus. Retail Manag. Res. www.jbrmr.com A J. Acad. Bus. Retail Manag., vol. 11, no. 3, pp. 64-71, 2017, Accessed: 02-May-2017. [Online]. Available: http://www.jbrmr.com/admin/content/pdf/content_650 13_17-04-22-11-45-45.pdf.

[20] M. N. Alraja and B. Chikhi, "Perceived Factors affecting Customers Attitudes toward Electronic Shopping: an Empirical Study," Int. J. Econ. Res., vol. 12, no. 3, pp. 815-823, 2015, Accessed: 17-May2019. [Online]. Available: http://serialsjournals.com/abstract/51627_17.pdf.

[21] M. A. Uddin, F. Ahmar, and M. N. Alraja, "Eexaminations for management students in Oman," Int. J. Appl. Bus. Econ. Res., vol. 14, no. 1, 2016.

[22] R. P. Singh Kaurav, S. Rajput, and R. Baber, "Factors Affecting the Acceptance of E-learning By Students: A Study of E-learning Programs in Gwalior, India," South Asian J. Manag., vol. 26, no. 1, pp. 76-95, 2019, Accessed: 31-Jul-2020. [Online]. Available: https://eds.b.ebscohost.com/eds/detail/detail?vid=0\&si $\mathrm{d}=660$ ed46c-cffb-4a42-81cd-b9749f1324db\%40pdc$\mathrm{v}-$

sessmgr06\&bdata=JnNpdGU9ZWRzLWxpdmU\%3D \#AN=137257943\&db=bsu.

[23] S. Keskin and H. Yurdugül, "Factors Affecting Students' Preferences for Online and Blended Learning: Motivational Vs. Cognitive," Eur. J. Open, Distance E-Learning, vol. 22, no. 2, pp. 72-86, Jan. 2020, doi: 10.2478/eurodl-2019-0011.

[24] E. Aïmeur, H. Hage, and F. S. Mani Onana, "A framework for privacy-preserving e-learning," in IFIP International Federation for Information Processing, 2007, vol. 238, pp. 223-238, doi: 10.1007/978-0-38773655-6_15.

[25] C. Kiennert, N. Kaaniche, M. Laurent, P. O. Rocher, and J. Garcia-Alfaro, "Anonymous certification for an e-assessment framework," in Lecture Notes in Computer Science (including subseries Lecture Notes in Artificial Intelligence and Lecture Notes in Bioinformatics), 2017, vol. 10674 LNCS, pp. 70-85, doi: 10.1007/978-3-319-70290-2_5.

[26] X. Deng and J. Ruan, "Users' privacy issues with elearning in library2.0," in 1st International Conference on Multimedia Information Networking and Security,
MINES 2009, 2009, vol. 1, pp. 90-92, doi: 10.1109/MINES.2009.96.

[27] J. Yong, "Digital identity design and privacy preservation for e-learning," in Proceedings of the 2007 11th International Conference on Computer Supported Cooperative Work in Design, CSCWD, 2007, pp. 858-863, doi: 10.1109/CSCWD.2007.4281549.

[28] J. Lang and P. Kysel, "Conceptual modeling in elearning and its relation to the educational content quality," in ICETA 2019 - 17th IEEE International Conference on Emerging eLearning Technologies and Applications, Proceedings, 2019, pp. 465-470, doi: 10.1109/ICETA48886.2019.9040028.

[29] A. Makina, "Developing a framework for managing the quality use of podcasts in open distance and elearning environments," Open Prax., vol. 12, no. 1, p. 67, Mar. 2020, doi: 10.5944/openpraxis.12.1.990.

[30] S. W. Widyaningsih and I. Yusuf, "Implementation of project-based learning (PjBL) assisted by e-learning through lesson study activities to improve the quality of learning in physics learning planning courses," Int. J. High. Educ., vol. 19, no. 1, pp. 60-68, Dec. 2020, doi: 10.5430/ijhe.v9n1p60.

[31] K. Gomez-Roman and I. Mata-Ortega, "Integration of the quality manager with the development model to guarantee the quality of products in an e-learning environment," in Proceedings - 13th Latin American Conference on Learning Technologies, LACLO 2018, 2018, pp. 17-20, doi: 10.1109/LACLO.2018.00013.

[32] T. S. Roberts, Online collaborative learning: Theory and practice. Hershey, PA: Information Science Publishing. , 2004.

[33] M. N. Alraja, S. F. Khan, B. Khashab, and R. Aldaas, "Does Facebook Commerce Enhance SMEs Performance? A Structural Equation Analysis of Omani SMEs," SAGE Open, vol. 10, no. 1, p. 215824401990018, Jan. 2020, doi: $10.1177 / 2158244019900186$.

[34] M. N. Alraja and M. A. Kashoob, "Transformation to electronic purchasing: an empirical investigation," TELKOMNIKA (Telecommunication Comput. Electron. Control., vol. 17, no. 3, pp. 1209-1219, Jun. 2019, doi: 10.12928/TELKOMNIKA.V17I3.9390.

[35] M. N. Alraja and N. M. M. Malkawi, "E-Business adoption in banking sector: Empirical study," Indian J. Sci. Technol., vol. 8, no. 27, 2015, doi: 10.17485/ijst/2015/v8i27/70739.

[36] M. N. Alraja and N. R. ALomiam, "THE EFFECT OF GENERAL CONTROLS OF INFORMATION SYSTEM AUDITING IN THE PERFORMANCE OF INFORMATION SYSTEMS :FIELD STUDY," Interdiscip. J. Contemp. Res. Bus., vol. 5, no. 3, pp. 356-370, 2013, Accessed: 03-Aug-2019. [Online]. Available: https://journal-archieves34.webs.com/356- 
370.pdf.

[37] M. N. Alraja, M. M. J. Farooque, and B. Khashab, "The Effect of Security, Privacy, Familiarity and Trust on Users' Attitudes Towards the Use of IoT-based Healthcare: The Mediation Role of RiskPerception," IEEE Access, vol. 7, pp. 1-1, 2019, doi: 10.1109/access.2019.2904006.

[38] M. N. Alraja and N. R. Alomian, "THE EFFECT OF INFORMATION TECHNOLOGY IN EMPOWERMENT PUBLIC SECTOR EMPLOYEES: A FIELD STUDY," Interdiscip. J. Contemp. Res. Bus., vol. 5, no. 1, pp. 805-815, 2013, Accessed: 17-May-2019. [Online]. Available: https://journal-archieves32.webs.com/805-815.pdf.

[39] N. M. M. A. Malkawi, M. N. Alraja, and T. Alkhayer, "Information Systems Auditing Applied Study at Banks Listed in the Damascus Stock Exchange Syria," Eur. J. Econ. Financ. Adm. Sci., no. 21, p. 119, 2010, Accessed: 17-May-2019. [Online]. Available: http://connection.ebscohost.com/c/articles/52428507/i nformation-systems-auditing-applied-study-bankslisted-damascus-stock-exchange-syria. 